\title{
From Mitochondria to Disease: Role of the Renin-Angiotensin System
}

\author{
E.M.V. de Cavanagh ${ }^{a} \quad$ F. Inserra ${ }^{a} \quad$ M. Ferder ${ }^{a} \quad$ L. Ferder ${ }^{b}$ \\ a Laboratory of Experimental Nephrology, Institute for Cardiovascular Research, School of Medicine, \\ University of Buenos Aires, Buenos Aires, Argentina; ${ }^{b}$ Physiology and Pharmacology Department, \\ Ponce School of Medicine, Ponce, PR, USA
}

\section{Key Words}

Aging • Oxidative stress $\cdot$ Angiotensin II $\cdot$ Mitochondria $\cdot$ Hypertension $\cdot$ Renin-angiotensin system $\cdot$ Cardiovascular disease $\cdot$ Kidney $\cdot$ Diabetes $\cdot$ Reactive oxygen species

\begin{abstract}
Mitochondria are energy-producing organelles that conduct other key cellular tasks. Thus, mitochondrial damage may impair various aspects of tissue functioning. Mitochondria generate oxygen- and nitrogen-derived oxidants, being themselves major oxidation targets. Dysfunctional mitochondria seem to contribute to the pathophysiology of hypertension, cardiac failure, the metabolic syndrome, obesity, diabetes mellitus, renal disease, atherosclerosis, and aging. Mitochondrial proteins and metabolic intermediates participate in various cellular processes, apart from their well-known roles in energy metabolism. This emphasizes the participation of dysfunctional mitochondria in disease, notwithstanding that most evidences supporting this concept come from animal and cultured-cell studies. Mitochondrial oxidant production is altered by several factors related to vascular pathophysiology. Among these, angiotensin-II stimulates mitochondrial oxidant release leading to energy metabolism depression. By lowering mitochondrial oxidant production, angiotensin-II inhibition enhances energy production and protects mitochondrial structure. This seems to be one of the mechanisms underlying the benefits of angiotensin-II inhibition in hypertension, diabetes, and aging
\end{abstract}

rodent models. If some of these findings can be reproduced in humans, they would provide a new perspective on the implications that RAS-blockade can offer as a therapeutic strategy. This review intends to present available information pointing to mitochondria as targets for therapeutic Ang-II blockade in human renal and CV disease.

Copyright $\odot 2007$ S. Karger AG, Basel

\section{Introduction}

Oxidative stress (OxStr), i.e. the sustained increase in the levels of oxidizing species, plays a key role in the pathophysiology of renal damage and cardiovascular disease (CVD). Renal lesions associated with hypertension, diabetes and glomerular diseases are among those that most frequently progress to chronic kidney disease (CKD). In addition, excess generation of reactive oxygen species (ROS), aggravated by the accompanying inflammatory syndrome, is mainly responsible for the acceleration of cardiovascular decay in CKD. Regardless of abundant information documenting the roles of OxStr and inflammatory processes in CKD and CVD, less is known on the involvement of mitochondria, i.e. the main cellular sources of ROS. Most of the evidence supporting a role for mitochondria in disease comes from studies in cultured cells and animal models. Recently, angiotensin-II (Ang-II) was found to stimulate not only cytosolic- but also mitochondrial-ROS generation, indicating that Ang-

Leon Ferder, MD

Physiology and Pharmacology Department, Ponce School of Medicine PO Box 7004

Ponce, PR 00732-7004 (USA)

Tel. +1 787841 3736,E-Mail leferder@psm.edu 
II-related tissue damage may involve mitochondrial OxStr. This review intends to present available information pointing to mitochondria as targets for therapeutic AngII blockade in human renal and CV disease.

\section{ROS Are Dual Agents}

ROS - including superoxide anion radical and hydrogen peroxide $\left(\mathrm{H}_{2} \mathrm{O}_{2}\right)$ - are continuous subproducts of normal aerobic metabolism that can oxidize nucleic acids, lipids and proteins, leading to the modification and/ or loss of their biological functions. Under pathophysiological conditions that exhibit increased levels of ROS, these oxidizing agents contribute to initiate and intensify the injurious events that accompany inflammation, degenerative diseases, hypertension, diabetes and oncogenesis $[1,2]$. However, under physiologically low ROS concentrations, these mediators constitute inter- and intracellular signals that, by oxidizing redox-sensitive protein phosphatases or kinases which are activated or inactivated in the process, can modify the phosphorylation status of transcription factors or receptors. This results in activity changes that are vital to maintain proper cellular function. Thus, depending on their cellular levels, ROS can act as either deleterious or crucial biological agents $[3,4]$.

In this regard, the identification of oxidized molecules in the kidney, and the protective action provided by antioxidants in animal models for human conditions, indicate a role for ROS in glomerular diseases [5].

\section{The Mitochondrion: A Multi-Task Organelle}

Mitochondria are energy-producing organelles that also conduct other key cellular tasks, including the regulation of cytosolic calcium levels [6] and tissue oxygen gradients [7], $\mathrm{H}_{2} \mathrm{O}_{2}$ signaling [8], and the modulation of apoptosis [9]. Importantly, mitochondria have emerged as organelles that receive, integrate and transmit signals, thus playing a critical role in cellular responses to a variety of stimuli [10]. Hence, it is apparent that mitochondrial damage may lead to the impairment of various aspects of tissue functioning.

\section{Mitochondria and ROS}

Mitochondria utilize more than $90 \%$ of cellular oxygen and, while most of it is transformed to water at complex IV of the mitochondrial electron transport chain
(mtETC), approximately $1-2 \%$ of the oxygen consumed [11] receive electrons directly from complexes I and III [12], to form superoxide. Other sources of mitochondrial ROS (mtROS) include electrons derived from complex II substrates that can be reverse-transported towards complex I and oxygen [13], matrix enzymes [14, 15], outer membrane monoaminoxidases (MAO) [16], and mitochondrial nitric oxide synthase (mtNOS) uncoupling [17]. Superoxide is released to both the mitochondrial matrix and the space between the inner and outer mitochondrial membrane [18] where it can be converted to $\mathrm{H}_{2} \mathrm{O}_{2}$ by $\mathrm{Mn}$ superoxide dismutase (Mn-SOD) and CuZnSOD, respectively $[19,20] . \mathrm{H}_{2} \mathrm{O}_{2}$ can be detoxified to water by mitochondrial glutathione peroxidase, or to water and oxygen by catalase, which is present in cardiac mitochondria. These enzymes belong to a complex multi-leveled mitochondrial defense system, composed of enzymes and non-enzymatic antioxidants, that is involved in ROS detoxification.

Additionally, mitochondria generate other oxidants derived from nitric oxide (NO), collectively known as reactive nitrogen species (RNS), that include peroxinitrite anion, which is formed when superoxide and NO react. Thus, mitochondria are relevant cellular sources of ROS and RNS, and consequently, are themselves major oxidation targets. This eventually leads to mitochondrial dysfunction, i.e. a defective capacity to generate ATP accompanied by increased ROS generation [21].

\section{Mitochondrial Dysfunction and Disease}

Mitochondrial dysfunction is detrimental to cells as a consequence of both the reduction of bioenergetic capacity and the derangement of mtROS-mediated signals. The contribution of dysfunctional mitochondria to disease is emphasized by the recent recognition that, in addition to their well-known roles in energy metabolism, mitochondrial proteins and metabolic intermediates participate in other processes. Thus, succinate dehydrogenase, an enzyme that contributes to mitochondrial oxidative phosphorylation by participating in the citric acid cycle, also seems to modulate mitochondrial $\mathrm{K}^{+}$transport by taking part in the formation of an inner membrane multiprotein complex that displays ATP-sensitive $\mathrm{K}^{+}$-channel activity [22]. Also, cytochrome $\mathrm{c}$, in addition to its key function as a mitochondrial electron carrier, participates as a signaling molecule in apoptosis [23]. Finally, the citric acid cycle intermediate succinate also acts as a signaling molecule through its binding to G-protein coupled receptors [24]. 
In this setting, malfunctioning mitochondria are involved in pathological conditions, such as hypertension [25-27], cardiac failure, the metabolic syndrome and obesity [28], diabetes mellitus [29,30], renal disease [31], atherosclerosis [32], as well as in aging [33].

\section{Mitochondria and Aging}

Oxidative damage to mitochondria, and the associated loss of mitochondrial function, not only contributes to disease, but was also postulated to be instrumental in the aging process. Accordingly, the mitochondrial free radical (FR) theory of aging [34] proposes that in aging cells accumulation of mitochondrial DNA (mtDNA) damage inflicted by FR generated by mitochondria, or at other cell sites, conducts to the progressive impairments of energy production, mitochondrial protein synthesis, and mitochondrial regeneration. In this way degenerative processes are initiated, eventually leading to the senescence-associated loss of functional capacity.

In support of the mitochondrial FR theory of aging, a reduction of mitochondrial number in certain organs is frequently associated with the aging process $[35,36]$. Also, tissues obtained from aged animals, display changes in mitochondrial structure [33] associated with increased superoxide and $\mathrm{H}_{2} \mathrm{O}_{2}$ generation, and decreased energy production $[37,38]$. Notably, as the efficiency of mtATP production declines due to damage by ROS, electron leakage from the mtETC increases, further augmenting FR generation, and giving rise to a self-sustained vicious cycle [39]. In this context, it was recently reported that mitochondria-targeted overexpression of catalase extends median and maximum mouse life-span [40]. This life extension coincided with decreases in mtDNA oxidant damage, mitochondrial $\mathrm{H}_{2} \mathrm{O}_{2}$ production, aconitase inactivation, and mtDNA deletion accumulation [40], supporting a link between mtROS generation, mitochondrial damage, and aging.

From another perspective, age-associated diseases, including hypertension, diabetes, cancer, and cardiovascular pathologies, are often accompanied by alterations in lipid metabolism, which is largely modulated by mitochondrial activity.

\section{Mitochondria and Apoptosis}

Present knowledge points to mitochondria as critical players in cell survival, as a consequence of their classical involvement in energy production and their crucial participation in apoptosis. Cell death results from either necrosis, when mtATP fails to be maintained at adequate levels, or apoptosis, when mtATP levels and mitochon- drial membrane potential (mtMP) are sustained, and mitochondria succeed in releasing pro-apototic proteins that act as molecular signals that initiate caspase activation [41].

In the kidney, mesangial cell (MC) apoptosis is seriously involved in glomerular remodeling after injury. MC behavior - regarding cell adhesion, replication, and extracellular matrix (ECM) production - is affected by changes in ECM composition associated with disease [42, 43]. Other examples of ECM influence on glomerular structure dynamics come from data showing that cell attachment to the ECM is required to abolish apoptosis [42], and normal ECM composition serves as a signal that prevents MC from undergoing apoptosis $[44,45]$. In this context, accumulating evidences show that mitochondria may act as sensors for changes in ECM composition [46, 47].

Depending on cell type, receptor subtype, and on interactions with other growth factors, Ang-II can induce differentiation, hypertrophy, proliferation, or apoptosis of vascular, cardiac, and renal cells. These Ang-II cell growth-related effects seem to contribute to the pathophysiology of atherosclerosis, vascular and cardiac remodeling, and progression to CKD [48]. AT2-receptor activation was suggested to be responsible for the apoptogenic actions of Ang-II; however, this point remains conflicting because AT1-receptor blockade also attenuates apoptosis in certain models $[49,50]$. Accordingly, work from our laboratory showed that renin-angiotensin system (RAS)-inhibition prevented the increase in myocardiocyte apoptosis that was observed in untreated aging mice [36], and this was accompanied by attenuation of myocardiosclerosis and decreased intracardiac artery wall-to-lumen ratios [51].

\section{mtROS Regulators}

Various factors are known to regulate mtROS production, including mtETC efficiency, mitochondrial antioxidant contents [52], local oxygen [53,54] and NO concentrations [55-57], the availability of metabolic electron donors [58], uncoupling protein (UCP) activity [59], and cytokines [60] (fig. 1). Additionally, several factors related to vascular pathophysiology can alter mtROS production, such as oxidized LDL [61, 62], free cholesterol [63], free and albumin-bound fatty acids [64-66], hyperglycemia [67], and, pertinent to this review, Ang-II [68, 69] (fig. 1). Interestingly, different therapeutic strategies aimed at modulating these factors - including thiazoli- 

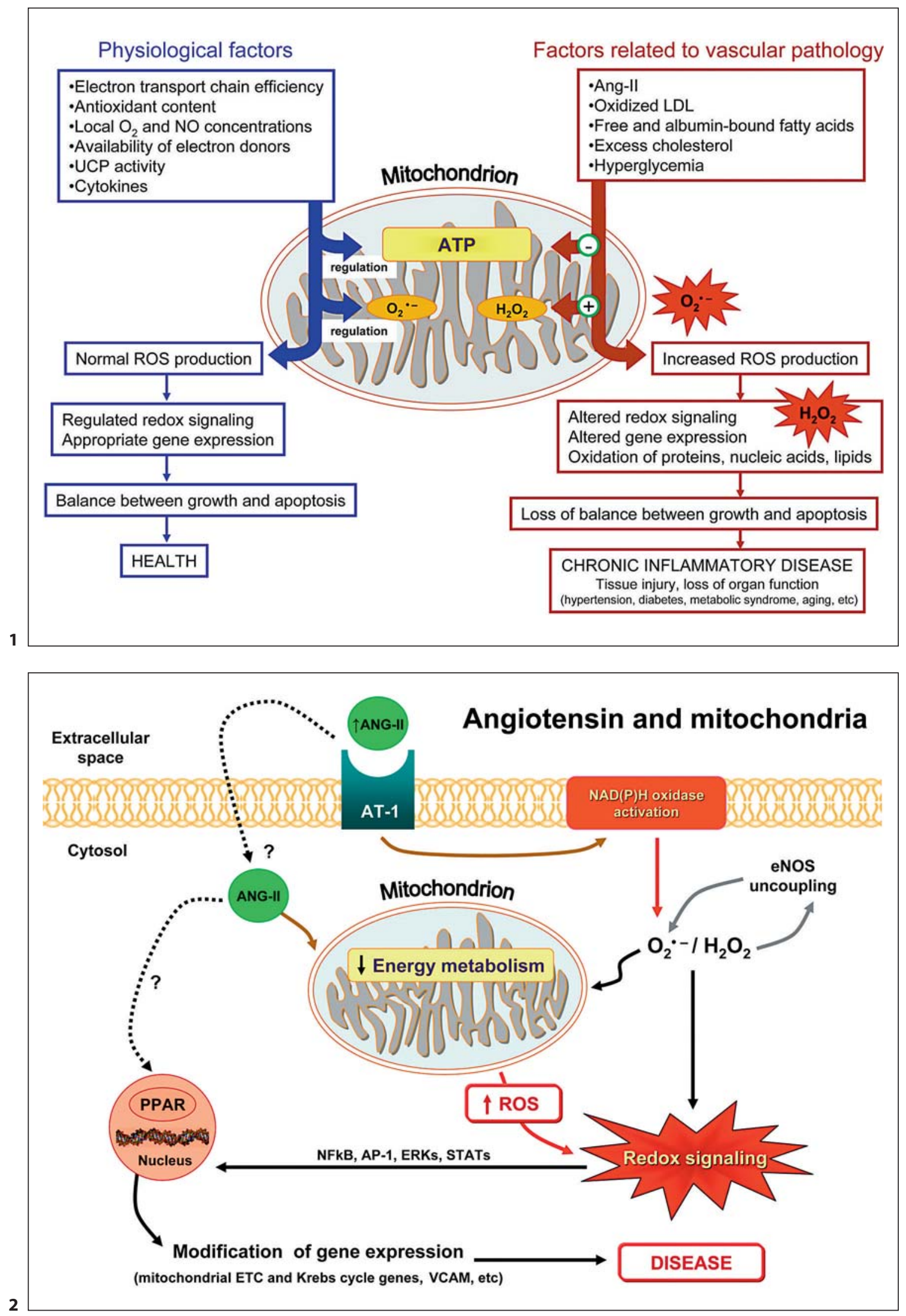
dinediones [70], statins [71], insulin [72], and Ang-II blockers - can attenuate mtROS production. Find below a revision concerning Ang-II inhibitor effects on mitochondrial functions ('Mitochondria and Ang-II inhibitors').

\section{Mitochondria and Ang-II}

Ang-II can promote OxStr by stimulating the generation of both NO [73] and NAD(P)H oxidase-derived superoxide [74], thereby enhancing peroxynitrite formation. Also, Ang-II can induce endothelial nitric oxide synthase (eNOS) to switch from NO to superoxide production [75]. In addition, a recent report indicates that Ang-II stimulates mtROS production in vascular smooth muscle cells and in rat aorta in vivo [69]. In bovine aortic endothelial cells, Ang-II prompts mitochondrial superoxide production as a result of vascular $\mathrm{NAD}(\mathrm{P}) \mathrm{H}$ oxidase activation [76] (fig. 2). A link between Ang-IIrelated ROS/RNS production and mitochondrial function was suggested by a report showing that antioxidants inhibit the regulatory effects of Ang-II on the AP-1 signaling pathway [77]. Since AP-1, whose activity responds to oxidation/reduction, regulates cytochrome c expression [78], it was suggested that Ang-II may facilitate changes in mitochondrial cytochrome $\mathrm{c}$ content [79].

Of note, in endothelial cells, Ang-II enhances mtROS generation, thus activating redox-sensitive NF-kappaB, which is followed by stimulation of vascular cell adhesion molecule-1 expression, a key molecule in atherosclerotic lesion initiation [68]. In mice, acute and chronic Ang-II infusion led to decreased cardiac mtETC and Krebs cycle gene expression [80], supporting previous observations indicating a role for Ang-II in the depression of mitochondrial energy metabolism [81-83]. Moreover, recent

Fig. 1. Factors that influence mitochondrial ROS generation. Fig. 2. mtROS are involved in redox cell signaling, but are also potential mediators of oxidative stress. Ang-II can promote oxidative stress by activating $\mathrm{NAD}(\mathrm{P}) \mathrm{H}$ oxidase-derived superoxide production, and/or by inducing eNOS to switch from NO to superoxide production. Also, Ang II-mediated enhancement of mtROS generation leads to the depression of mitochondrial energy metabolism, and a direct interaction between Ang-II and mitochondrial components by-passes activation of NAD $(\mathrm{P}) \mathrm{H}$ oxidase. Thus, Ang-II can lead to changes in gene expression that may result in disease. Ang-II inhibition is expected to lower $\mathrm{mtROS}$ release, increasing the efficiency of the respiratory chain and protecting mitochondrial structure.

Mitochondria and the Renin-Angiotensin System findings show that Ang-II lowers mtMP as a result of stimulation of mtROS production $[69,84]$.

Also, there are evidences indicating a direct interaction between Ang-II and mitochondrial components. In studies using ${ }^{125}$ I-labeled Ang-II, Ang-II was detected in heart, brain and smooth muscle cell mitochondria and nuclei $[85,86]$. In rat adrenal zona glomerulosa, renin, angiotensinogen and angiotensin-converting enzyme (ACE) were detected within intramitochondrial dense bodies [87]. Ang-II immunoreactivity was also observed in rat cerebellar cortex mitochondria [88]. Hence, it is possible to speculate that Ang-II may have direct actions on mitochondria, independent of AT1-receptor signalling (fig. 2).

Under normal physiological conditions, Ang-II-mediated ROS- and NO-derived oxidant production, and the resulting stimulation of redox-sensitive signaling pathways, are closely regulated [89]. However, under conditions associated with RAS overactivation, including hypertension, diabetes [90, 91] and aging [92-95], dysregulation of Ang-II-dependent ROS generation may become a significant contributor to cell oxidation and tissue damage (fig. 2). In this context, studies from our laboratory showed that in rodent models of hypertension, diabetes and aging, Ang-II blockade not only attenuates oxidant production, but also improves mitochondrial function $[26,27,30,33]$.

\section{Mitochondria and Ang-II Inhibitors}

The renal and cardiac benefits of ACE-inhibitors and Ang-II type 1 receptor (AT1) blockers in hypertension, cardiovascular disease and diabetes patients [96-98] seem to be - at least partly - independent from their blood pressure lowering actions [96, 98-100], suggesting that these drugs can execute direct tissue effects that do not result from their hemodynamic actions. In this regard, RAS-inhibitors were proposed to act as a magic bullet against OxStr [101].

Considering that (a) Ang-II inhibitors are indicated for the treatment of hypertension and cardiac failure, (b) international guide recommendations exist for the use of Ang-II inhibitors as first-line drug therapy for kidney protection in diabetic patients, even in the absence of hypertension [102], (c) the cellular mechanisms responsible for Ang-II inhibitors protective effects are poorly understood, and (d) malfunctioning mitochondria seem to be involved in the pathogenesis of a variety of disease conditions, we set forth to investigate Ang-II inhibitors effects on mitochondria. The first study showed that ACE-inhi- 
bition (enalapril) in aging mice prevented the lowering of mitochondrial number [35], and attenuated age-related mitochondrial structure changes in myocardiocytes and hepatocytes [unpubl. results]. These protective effects of enalapril were associated with a significant increase in animal survival, suggesting that natural aging mechanisms had been altered in enalapril-treated animals. The latter action on mice survival is in agreement with recent data in aging rats [103].

Later, we found that long-term RAS inhibition during aging, with enalapril or AT1-blocker (losartan), improved kidney mitochondria mtATP production, lowered $\mathrm{H}_{2} \mathrm{O}_{2}$ generation, and enhanced mtNOS activity and UCP-2 content, when compared with mitochondria isolated from untreated old rats [33]. In the same study, a general improvement in mitochondrial number and structure was observed, indicating that RAS inhibition, regardless of how it is implemented, protects mitochondrial components and function from certain effects of aging.

Evidence pointing to mitochondrial dysfunction as a contributing factor to the pathophysiology of hypertension [104] led us to address the possibility that, in addition to the results obtained in aging rats, RAS inhibition might protect mitochondria from hypertension-related damage.

In spontaneously hypertensive rat (SHR) kidneys, chronic Ang-II blockade prevented the decreases in mtMP, NOS, UCP-2 content, Mn-SOD and cytochrome oxidase activities, and the increase in $\mathrm{H}_{2} \mathrm{O}_{2}$ production observed in untreated SHR $[26,27]$. The mitochondrial protective action displayed by losartan treatment was absent in amlodipine-treated SHR. Furthermore, in untreated and in amlodipine-treated SHR, mitochondrial impairment was accompanied by renal damage. Taken together, the above findings indicate that AT1-blockade attenuates mitochondrial dysfunction in SHR, and this may underlie the beneficial actions of AT1-blockade on kidney structure and function [26].

Recent data indicating that the kidneys are main targets of mitochondrial impairment at the onset of and throughout streptozotocin-induced diabetes - a model of type- 1 diabetes - and that insulin treatment is unable to restore normal mitochondrial function [105], led us to investigate whether AT1-blockade might protect mitochondria against the effects of diabetes. In streptozotocin-diabetic rats, losartan protected kidney mitochon-

that the contrasting effects displayed by losartan and amlodipine on kidney mitochondrial function may be, at least partly, a consequence of losartan-mediated blockade of Ang-II actions (see above 'Mitochondria and AngII'). In agreement with our findings in the kidney, work by other groups support the notion that Ang-II inhibition improves cardiac mitochondria energy production [106108]. In this line, a recent study showed that the expression of genes related to energy production were up-regulated in captopril-treated diabetic rats [109].

Concerning the potential factor(s) that may mediate the effects of Ang-II inhibitors on mitochondrial function, a study showed that in normotensive enalapril-treated rats, kidney mitochondrial electron transfer activities were lower, and UCP-2 content significantly higher, than in untreated controls. These changes were accompanied by a higher production/bioavailability of kidney NO, and were prevented by co-treatment with L-NAME (a NOS inhibitor). L-NAME abolished mtNOS activity, but failed to inhibit extra-mitochondrial kidney NOS, underscoring the relevance of mitochondrial NO in mediating those effects of enalapril that were suppressed by LNAME co-treatment [110].

\section{Summary and Conclusion}

Mitochondria are main sources of both of cellular energy and ROS. mtROS are involved in cell signaling, but are also potential mediators of OxStr. Available evidences suggest that Ang-II enhances mtROS generation leading to the depression of mitochondrial energy metabolism (fig. 2). Consequently, Ang-II inhibition lowers mtROS release, increasing the efficiency of mtETC and protecting mitochondrial structure. This seems to be one of the mechanisms underlying the beneficial effects of Ang-II inhibition in rodent models of hypertension, diabetes, and normal aging. If some of these findings can be reproduced in humans, they would provide a new perspective on the implications that RAS blockade can offer as a therapeutic strategy. dria against changes in mtMP, $\mathrm{H}_{2} \mathrm{O}_{2}$ production and pyruvate content, without normalizing plasma glucose. Conversely, amlodipine was equally potent as losartan as an hypertensive agent, but showed no beneficial effects on kidney mitochondrial changes [30]. It can be proposed

References
1 Cerutti PA, Trump BF: Inflammation and oxidative stress in carcinogenesis. Cancer Cells 1991;3:1-7.
2 Halliwell B, Gutteridge, JMC: Free Radicals, Other Reactive Species and Disease Free Radicals in Biology and Medicine. Oxford, Oxford Press, 1999, pp 617-783.


3 Suzuki YJ, Forman HJ, Sevanian A: Oxidants as stimulators of signal transduction. Free Radic Biol Med 1997;22:269-285.

$\checkmark 4$ Gutteridge JM, Halliwell B: Free radicals and antioxidants in the year 2000: a historical look to the future. Ann NY Acad Sci 2000; 899:136-147.

55 Gwinner W, Grone HJ: Role of reactive oxygen species in glomerulonephritis. Nephrol Dial Transplant 2000;15:1127-1132.

-6 Duszynski J, Koziel R, Brutkowski W, Szczepanowska J, Zablocki K: The regulatory role of mitochondria in capacitative calcium entry. Biochim Biophys Acta 2006;1757:380387.

7 Thomas DD, Liu X, Kantrow SP, Lancaster JR Jr: The biological lifetime of nitric oxide: implications for the perivascular dynamics of $\mathrm{NO}$ and $\mathrm{O}_{2}$. Proc Natl Acad Sci USA 2001; 98:355-360.

$\checkmark 8$ Brookes P, Darley-Usmar VM: Hypothesis: The mitochondrial $\left.\mathrm{NO}^{*}\right)$ signaling pathway, and the transduction of nitrosative to oxidative cell signals: an alternative function for cytochrome c oxidase. Free Radic Biol Med 2002;32:370-374.

$\checkmark 9$ Brookes PS, Salinas EP, Darley-Usmar K, Eiserich JP, Freeman BA, Darley-Usmar VM, Anderson PG: Concentration-dependent effects of nitric oxide on mitochondrial permeability transition and cytochrome c release. J Biol Chem 2000;275:20474-20479.

>10 Goldenthal MJ, Marin-Garcia J: Mitochondrial signaling pathways: a receiver/integrator organelle. Mol Cell Biochem 2004;262: $1-16$.

11 Chance B, Sies H, Boveris A: Hydroperoxide metabolism in mammalian organs. Physiol Rev 1979;59:527-605.

12 Turrens JF: Mitochondrial formation of reactive oxygen species. J Physiol 2003;552: 335-344.

-13 Grivennikova VG, Vinogradov AD: Generation of superoxide by the mitochondrial complex I. Biochim Biophys Acta 2006;1757: 553-561.

-14 Messner KR, Imlay JA: Mechanism of superoxide and hydrogen peroxide formation by fumarate reductase, succinate dehydrogenase, and aspartate oxidase. J Biol Chem 2002;277:42563-42571.

- 15 Starkov AA, Fiskum G, Chinopoulos C, Lorenzo BJ, Browne SE, Patel MS, Beal MF: Mitochondrial alpha-ketoglutarate dehydrogenase complex generates reactive oxygen species. J Neurosci 2004;24:7779-7788.

16 Cadenas E, Davies KJ: Mitochondrial free radical generation, oxidative stress, and aging. Free Radic Biol Med 2000;29:222-230.

-17 Brodsky SV, Gao S, Li H, Goligorsky MS: Hyperglycemic switch from mitochondrial nitric oxide to superoxide production in endothelial cells. Am J Physiol 2002;283: H2130-2139.
18 Muller FL, Liu Y, Van Remmen H: Complex III releases superoxide to both sides of the inner mitochondrial membrane. J Biol Chem 2004;279:49064-49073.

19 Andreyev AY, Kushnareva YE, Starkov AA: Mitochondrial metabolism of reactive oxygen species. Biochemistry (Mosc) 2005;70: 200-214.

20 Okado-Matsumoto A, Fridovich I: Subcellular distribution of superoxide dismutases (SOD) in rat liver: $\mathrm{Cu}, \mathrm{Zn}-\mathrm{SOD}$ in mitochondria. J Biol Chem 2001;276:38388-38393.

21 Shigenaga MK, Hagen TM, Ames BN: Oxidative damage and mitochondrial decay in aging. Proc Natl Acad Sci USA 1994;91: 10771-10778.

22 Ardehali H, Chen Z, Ko Y, Mejia-Alvarez R, Marban E: Multiprotein complex containing succinate dehydrogenase confers mitochondrial ATP-sensitive $\mathrm{K}+$ channel activity. Proc Natl Acad Sci USA 2004;101:1188011885.

23 Gogvadze V, Orrenius S, Zhivotovsky B: Multiple pathways of cytochrome $c$ release from mitochondria in apoptosis. Biochim Biophys Acta 2006;1757:639-647.

$24 \mathrm{He}$ W, Miao FJ, Lin DC, Schwandner RT, Wang Z, Gao J, Chen JL, Tian H, Ling L: Citric acid cycle intermediates as ligands for orphan G-protein-coupled receptors. Nature 2004;429:188-193.

25 Touyz RM: Reactive oxygen species, vascular oxidative stress, and redox signaling in hypertension: what is the clinical significance? Hypertension 2004;44:248-252.

26 de Cavanagh EM, Toblli JE, Ferder L, Piotrkowski B, Stella I, Inserra F: Renal mitochondrial dysfunction in spontaneously hypertensive rats is attenuated by losartan but not by amlodipine. Am J Physiol 2006;290: R1616-R1625.

27 De Cavanagh EM, Toblli JE, Ferder L, Piotrkowski B, Stella I, Fraga CG, Inserra F: Angiotensin II blockade improves mitochondrial function in spontaneously hypertensive rats. Cell Mol Biol (Noisy-le-grand) 2005;51:573-578.

28 Wisloff U, Najjar SM, Ellingsen O, Haram PM, Swoap S, Al-Share Q, Fernstrom M, Rezaei K, Lee SJ, Koch LG, Britton SL: Cardiovascular risk factors emerge after artificial selection for low aerobic capacity. Science 2005;307:418-420.

29 Wallace DC: Mitochondrial diseases in man and mouse. Science 1999;283:1482-1488.

30 de Cavanagh E, Piotrkowski, B, Fraga, CG Ferder, L, Inserra, F: Losartan ameliorates renal mitochondrial function in streptozotocin-induced diabetes (abstract). XIV Eur Meet on Hypertension, Paris, 2004.

-31 Hall AM, Unwin RJ: The not so 'mighty chondrion': emergence of renal diseases due to mitochondrial dysfunction. Nephron Physiol 2007;105:1-10.

-32 Semenkovich CF: Insulin resistance and atherosclerosis. J Clin Invest 2006;116:18131822 .
33 de Cavanagh EM, Piotrkowski B, Basso N, Stella I, Inserra F, Ferder L, Fraga CG: Enalapril and losartan attenuate mitochondrial dysfunction in aged rats. FASEB J 2003;17: 1096-1098.

34 Miquel J: An update on the oxygen stress-mitochondrial mutation theory of aging: genetic and evolutionary implications. Exp Gerontol 1998;33:113-126.

-35 Ferder L, Inserra F, Romano L, Ercole L, Pszenny V: Effects of angiotensin-converting enzyme inhibition on mitochondrial number in the aging mouse. Am J Physiol 1993;265:C15-C18.

>36 Ferder L, Romano LA, Ercole LB, Stella I, Inserra F: Biomolecular changes in the aging myocardium: the effect of enalapril. Am J Hypertens 1998;11:1297-1304.

37 Sohal RS, Ku HH, Agarwal S, Forster MJ, Lal $\mathrm{H}$ : Oxidative damage, mitochondrial oxidant generation and antioxidant defenses during aging and in response to food restriction in the mouse. Mech Age Dev 1994;74: 121-133.

>38 Sastre J, Millan A, Garcia de la Asuncion J, Pla R, Juan G, Pallardo, O’Connor E, Martin JA, Droy-Lefaix MT, Vina J: A Ginkgo biloba extract (Egb 761) prevents mitochondrial aging by protecting against oxidative stress. Free Radic Biol Med 1998;24:298-304.

>39 Beckman KB, Ames BN: Mitochondrial aging: open questions. Ann NY Acad Sci 1998; 854:118-127.

40 Schriner SE, Linford NJ, Martin GM, Treuting P, Ogburn CE, Emond M, Coskun PE, Ladiges W, Wolf N, Van Remmen H, Wallace DC, Rabinovitch PS: Extension of murine life span by overexpression of catalase targeted to mitochondria. Science 2005; 308:1909-1911.

41 Skulachev VP: Bioenergetic aspects of apoptosis, necrosis and mitoptosis. Apoptosis 2006;11:473-485

42 Rupprecht HD, Schocklmann HO, Sterzel RB: Cell-matrix interactions in the glomerular mesangium. Kidney Int 1996;49:15751582

43 Sterzel RB, Schulze-Lohoff E, Marx M: Cytokines and mesangial cells. Kidney Int Suppl 1993;39:S26-S31.

44 Sugiyama H, Kashihara N, Maeshima Y, Okamoto K, Kanao K, Sekikawa T, Makino $\mathrm{H}$ : Regulation of survival and death of mesangial cells by extracellular matrix. Kidney Int 1998;54:1188-1196.

45 Makino H, Sugiyama H, Kashihara N: Apoptosis and extracellular matrix-cell interactions in kidney disease. Kidney Int Suppl 2000;77:S67-S75

46 Irwin WA, Bergamin N, Sabatelli P, Reggiani C, Megighian A, Merlini L, Braghetta P, Columbaro M, Volpin D, Bressan GM, Bernardi P, Bonaldo P: Mitochondrial dysfunction and apoptosis in myopathic mice with collagen VI deficiency. Nat Genet 2003;35:367371. 
47 Wu D, Chen X, Guo D, Hong Q, Fu B, Ding $\mathrm{R}$, Yu L, Hou K, Feng Z, Zhang X, Wang J: Knockdown of fibronectin induces mitochondria-dependent apoptosis in rat mesangial cells. J Am Soc Nephrol 2005;16:646657.

-48 Wolf G, Wenzel UO: Angiotensin II and cell cycle regulation. Hypertension 2004;43: 693-698.

- 49 Goldenberg I, Grossman E, Jacobson KA, Shneyvays V, Shainberg A: Angiotensin IIinduced apoptosis in rat cardiomyocyte culture: a possible role of AT1 and AT2 receptors. J Hypertens 2001;19:1681-1689.

-50 Li D, Yang B, Philips MI, Mehta JL: Proapoptotic effects of Ang II in human coronary artery endothelial cells: role of AT1 receptor and PKC activation. Am J Physiol 1999;276: H786-H792.

- 51 Inserra F, Romano L, Ercole L, de Cavanagh EM, Ferder L: Cardiovascular changes by long-term inhibition of the renin-angiotensin system in aging. Hypertension 1995;25: 437-442.

52 Manna SK, Zhang HJ, Yan T, Oberley LW, Aggarwal BB: Overexpression of manganese superoxide dismutase suppresses tumor necrosis factor-induced apoptosis and activation of nuclear transcription factor-kappa-b and activated protein-1. J Biol Chem 1998; 273:13245-13254.

-53 Boveris A, Chance B: The mitochondrial generation of hydrogen peroxide: general properties and effect of hyperbaric oxygen. Biochem J 1973;134:707-716.

-54 Alvarez S, Valdez LB, Zaobornyj T, Boveris A: Oxygen dependence of mitochondrial nitric oxide synthase activity. Biochem Biophys Res Commun 2003;305:771-775.

- 55 Poderoso JJ, Carreras MC, Lisdero C, Riobo $\mathrm{N}$, Schopfer F, Boveris A: Nitric oxide inhibits electron transfer and increases superoxide radical production in rat heart mitochondria and submitochondrial particles. Arch Biochem Biophys 1996;328:85-92.

56 Boveris A, Costa LE, Poderoso JJ, Carreras MC, Cadenas E: Regulation of mitochondrial respiration by oxygen and nitric oxide. Ann NY Acad Sci 2000;899:121-135.

-57 Ramachandran A, Ceaser E, Darley-Usmar VM: Chronic exposure to nitric oxide alters the free iron pool in endothelial cells: role of mitochondrial respiratory complexes and heat shock proteins. Proc Natl Acad Sci USA 2004;101:384-389.

- 58 Loschen G, Flohe L, Chance B: Respiratory chain linked $\mathrm{H}(2) \mathrm{O}(2)$ production in pigeon heart mitochondria. FEBS Lett 1971;18:261264.

-59 Brand MD, Affourtit C, Esteves TC, Green K, Lambert AJ, Miwa S, Pakay JL, Parker N: Mitochondrial superoxide: production, biological effects, and activation of uncoupling proteins. Free Radic Biol Med 2004;37:755767.
60 Schulze-Osthoff K, Bakker AC, Vanhaesebroeck B, Beyaert R, Jacob WA, Fiers W: Cytotoxic activity of tumor necrosis factor is mediated by early damage of mitochondrial functions: evidence for the involvement of mitochondrial radical generation. J Biol Chem 1992;267:5317-5323.

61 Ceaser EK, Ramachandran A, Levonen AL, Darley-Usmar VM: Oxidized low-density lipoprotein and 15-deoxy-delta-12,14-PGJ2 increase mitochondrial complex I activity in endothelial cells. Am J Physiol 2003;285: H2298-H2308.

62 Asmis R, Begley JG: Oxidized LDL promotes peroxide-mediated mitochondrial dysfunction and cell death in human macrophages: a caspase-3-independent pathway. Circ Res 2003;92:e20-e29.

63 Mari M, Caballero F, Colell A, Morales A, Caballeria J, Fernandez A, Enrich C, Fernandez-Checa JC, Garcia-Ruiz C: Mitochondrial free cholesterol loading sensitizes to TNFand Fas-mediated steatohepatitis. Cell Metab 2006;4:185-198.

64 Korge P, Honda HM, Weiss JN: Effects of fatty acids in isolated mitochondria: implications for ischemic injury and cardioprotection. Am J Physiol 2003;285:H259-H269.

65 RachekLI, Thornley NP, Grishko VI, LeDoux SP, Wilson GL: Protection of ins-1 cells from free fatty acid-induced apoptosis by targeting hOGG1 to mitochondria. Diabetes 2006; 55:1022-1028.

66 Ishola DA, Jr., Post JA, van Timmeren MM, Bakker SJ, Goldschmeding R, Koomans HA, Braam B, Joles JA: Albumin-bound fatty acids induce mitochondrial oxidant stress and impair antioxidant responses in proximal tubular cells. Kidney Int 2006;70:724-731.

67 Nishikawa T, Edelstein D, Du XL, Yamagishi S, Matsumura T, Kaneda Y, Yorek MA, Beebe D, Oates PJ, Hammes HP, Giardino I, Brownlee M: Normalizing mitochondrial superoxide production blocks three pathways of hyperglycaemic damage. Nature 2000;404: 787-790.

68 Pueyo ME, Gonzalez W, Nicoletti A, Savoie F, Arnal JF, Michel JB: Angiotensin II stimulates endothelial vascular cell adhesion molecule-1 via nuclear factor-kappaB activation induced by intracellular oxidative stress. Arterioscler Thromb Vasc Biol 2000;20:645651.

69 Kimura S, Zhang GX, Nishiyama A, Shokoji T, Yao L, Fan YY, Rahman M, Abe Y: Mitochondria-derived reactive oxygen species and vascular map kinases: comparison of angiotensin II and diazoxide. Hypertension 2005;45:438-444.

70 Shishido S, Koga H, Harada M, Kumemura $\mathrm{H}$, Hanada S, Taniguchi E, Kumashiro R, Ohira H, Sato Y, Namba M, Ueno T, Sata M: Hydrogen peroxide overproduction in megamitochondria of troglitazone-treated human hepatocytes. Hepatology 2003;37:136147.
-71 Jones SP, Teshima Y, Akao M, Marban E: Simvastatin attenuates oxidant-induced mitochondrial dysfunction in cardiac myocytes. Circ Res 2003;93:697-699.

72 Moreira PI, Rolo AP, Sena C, Seica R, Oliveira CR, Santos MS: Insulin attenuates diabetes-related mitochondrial alterations: a comparative study. Med Chem 2006;2:299-308.

73 Pueyo ME, Arnal JF, Rami J, Michel JB: Angiotensin II stimulates the production of $\mathrm{NO}$ and peroxynitrite in endothelial cells. Am J Physiol 1998;274:C214-220.

74 Rueckschloss U, Quinn MT, Holtz J, Morawietz $\mathrm{H}$ : Dose-dependent regulation of $\mathrm{NAD}(\mathrm{P}) \mathrm{H}$ oxidase expression by angiotensin II in human endothelial cells: protective effect of angiotensin II type 1 receptor blockade in patients with coronary artery disease. Arterioscler Thromb Vasc Biol 2002;22: 1845-1851

75 Mollnau H, Wendt M, Szocs K, Lassegue B, Schulz E, Oelze M, Li H, Bodenschatz M, August M, Kleschyov AL, Tsilimingas N, Walter U, Forstermann U, Meinertz T, Griendling K, Munzel T: Effects of angiotensin II infusion on the expression and function of $\mathrm{NAD}(\mathrm{P}) \mathrm{H}$ oxidase and components of nitric oxide/cGMP signaling. Circ Res 2002;90: E58-E65.

76 Doughan A, Dikalov, S: Angiotensin II increases mitochondrial superoxide production in endothelial cells: a potential link between NADPH oxidase and mitochondrial dysfunction; in Davies K (ed): SFRBM 12th Annual Meeting: Program and Abstracts. Free Radic Biol Med 2005;39(suppl 1):S23.

77 Puri PL, Avantaggiati ML, Burgio VL, Chirillo P, Collepardo D, Natoli G, Balsano C, Levrero M: Reactive oxygen intermediates mediate angiotensin II-induced c-jun. C-fos heterodimer DNA binding activity and proliferative hypertrophic responses in myogenic cells. J Biol Chem 1995;270:2212922134.

78 Xia Y, Buja LM, McMillin JB: Activation of the cytochrome $\mathrm{c}$ gene by electrical stimulation in neonatal rat cardiac myocytes: role of nrf-1 and c-jun. J Biol Chem 1998;273:1259312598.

79 Leary SC, Michaud D, Lyons CN, Hale TM, Bushfield TL, Adams MA, Moyes CD: Bioenergetic remodeling of heart during treatment of spontaneously hypertensive rats with enalapril. Am J Physiol 2002;283:H540H548.

80 Larkin JE, Frank BC, Gaspard RM, Duka I, Gavras H, Quackenbush J: Cardiac transcriptional response to acute and chronic angiotensin II treatments. Physiol Genomics 2004:18:152-166

81 Casademont J, Miro O: Electron transport chain defects in heart failure. Heart Fail Rev 2002;7:131-139. 
-82 Sanbe A, Tanonaka K, Kobayasi R, Takeo S: Effects of long-term therapy with ACE inhibitors, captopril, enalapril and trandolapril, on myocardial energy metabolism in rats with heart failure following myocardial infarction. J Mol Cell Cardiol 1995;27:2209-2222.

$\checkmark 83$ Sorescu D, Griendling KK: Reactive oxygen species, mitochondria, and $\mathrm{NAD}(\mathrm{P}) \mathrm{H}$ oxidases in the development and progression of heart failure. Congest Heart Fail 2002;8:132140.

-84 Hastings R, Stanley A, Lacy P, Li N, Williams $\mathrm{B}$ : Angiotensin II induces DNA injury in human umbilical artery smooth muscle cells via a mechanism which involves hydrogen peroxide. Am J Hypertens 2002;15:A13.

>85 Robertson AL Jr, Khairallah PA: Angiotensin II: Rapid localization in nuclei of smooth and cardiac muscle. Science 1971;172:11381139.

-86 Sirett NE, McLean AS, Bray JJ, Hubbard JI: Distribution of angiotensin II receptors in rat brain. Brain Res 1977;122:299-312.

-87 Peters J, Kranzlin B, Schaeffer S, Zimmer J, Resch S, Bachmann S, Gretz N, Hackenthal E: Presence of renin within intramitochondrial dense bodies of the rat adrenal cortex. Am J Physiol 1996;271:E439-E450.

-88 Erdmann B, Fuxe K, Ganten D: Subcellular localization of angiotensin II immunoreactivity in the rat cerebellar cortex. Hypertension 1996;28:818-824.

$>89$ Touyz RM: Activated oxygen metabolites: Do they really play a role in angiotensin IIregulated vascular tone? J Hypertens 2003; 21:2235-2238.

-90 Touyz RM, Schiffrin EL: Signal transduction mechanisms mediating the physiological and pathophysiological actions of angiotensin II in vascular smooth muscle cells. Pharmacol Rev 2000;52:639-672.

-91 Rincon-Choles H, Kasinath BS, Gorin Y, Abboud HE: Angiotensin II and growth factors in the pathogenesis of diabetic nephropathy. Kidney Int Suppl 2002:8-11.

92 Wang M, Takagi G, Asai K, Resuello RG, Natividad FF, Vatner DE, Vatner SF, Lakatta EG: Aging increases aortic MMP-2 activity and angiotensin II in nonhuman primates. Hypertension 2003;41:1308-1316.
-93 Harada K, Ohmori M, Fujimura A: Vasoconstricting effect of angiotensin II in human hand veins: influence of aging, diabetes mellitus and hypertension. Hypertens Res 2002;25:683-688.

94 Thompson MM, Oyama TT, Kelly FJ, Kennefick TM, Anderson S: Activity and responsiveness of the renin-angiotensin system in the aging rat. Am J Physiol 2000;279: R1787-1794.

$\checkmark 95$ Baylis C, Engels K, Hymel A, Navar LG: Plasma renin activity and metabolic clearance rate of angiotensin II in the unstressed aging rat. Mech Age Dev 1997;97:163-172.

$\checkmark 96$ Dahlof B, Devereux RB, Julius S, Kjeldsen SE, Beevers G, de Faire U, Fyhrquist F, Hedner T, Ibsen $\mathrm{H}$, Kristianson K, LederballePedersen O, Lindholm LH, Nieminen MS, Omvik P, Oparil S, Wedel H: Characteristics of 9194 patients with left ventricular hypertrophy: the life study. Losartan intervention for endpoint reduction in hypertension. Hypertension 1998;32:989-997.

-97 Pfeffer MA, Braunwald E, Moye LA, Basta L, Brown EJ Jr, Cuddy TE, Davis BR, Geltman EM, Goldman S, Flaker GC, et al: Effect of captopril on mortality and morbidity in patients with left ventricular dysfunction after myocardial infarction. Results of the survival and ventricular enlargement trial: The SAVE Investigators. N Engl J Med 1992;327:669-677.

-98 Bosch J, Lonn E, Pogue J, Arnold JM, Dagenais GR, Yusuf S: Long-term effects of ramipril on cardiovascular events and on diabetes: results of the HOPE study extension. Circulation 2005;112:1339-1346.

$\checkmark 99$ Park JB, Intengan HD, Schiffrin EL: Reduction of resistance artery stiffness by treatment with the AT(1)-receptor antagonist losartan in essential hypertension. J Renin Angiotensin Aldosterone Syst 2000;1:4045.

100 Opie LH: Renoprotection by angiotensinreceptor blockers and ACE inhibitors in hy pertension. Lancet 2001;358:1829-1831.

101 Munzel T, Keaney JF Jr: Are ACE inhibitors a 'magic bullet' against oxidative stress? Circulation 2001;104:1571-1574.
102 Molitch ME, DeFronzo RA, Franz MJ, Keane WF, Mogensen CE, Parving HH, Steffes MW: Nephropathy in diabetes. Diabetes Care 2004;27(suppl 1):S79-S83.

103 Basso N, Cini R, Pietrelli A, Ferder L, Terragno NA, Inserra F: Cardiovascular aging: Protective effect of long-term angiotensin II inhibition. Am J Physiol Heart Circ Physiol 2007; in press.

104 Ramachandran A, Levonen AL, Brookes PS, Ceaser E, Shiva S, Barone MC, DarleyUsmar V: Mitochondria, nitric oxide, and cardiovascular dysfunction. Free Radic Biol Med 2002;33:1465-1474.

105 Katyare SS, Satav JG: Effect of streptozotocin-induced diabetes on oxidative energy metabolism in rat kidney mitochondria: a comparative study of early and late effects. Diabetes Obes Metab 2005;7:555-562.

106 Monteiro P, Duarte AI, Goncalves LM, Providencia LA: Valsartan improves mitochondrial function in hearts submitted to acute ischemia. Eur J Pharmacol 2005;518: 158-164.

107 Monteiro P, Gala S, Nobre S, Carreira R, Goncalves LM, Providencia LA: Impact of imidapril on cardiac mitochondrial function in an ex-vivo animal model of global myocardial ischemia. Rev Port Cardiol 2005;24:53-61.

108 Benderdour M, Charron G, Comte B, Ayoub R, Beaudry D, Foisy S, Deblois D, Des Rosiers C: Decreased cardiac mitochondrial NADP+-isocitrate dehydrogenase activity and expression: a marker of oxidative stress in hypertrophy development. Am J Physiol 2004;287:H2122-H2131.

109 Chen G, Lin LX, Zhuang WT, Yao J, Huang HB, Liang JX, Zhang FL, Wen JP, Li LT, Lin M, Lin QM: Effects of captopril on myocardial tissue energy metabolism and inflammation in rats with diabetic cardiomyopathy. Di Yi Jun Yi Da Xue Xue Bao 2004;24: 827-828, 831 .

110 Piotrkowski B, Fraga CG, de Cavanagh EM: Mitochondrial function and nitric oxide metabolism are modified by enalapril treatment in rat kidney. Am J Physiol 2007;292: R1494-R1501. 